\title{
A scanning electron microscope study of the hatching of bovine blastocysts in vitro
}

\author{
J.-E. Fléchon and J.-P. Renard \\ Station centrale de Physiologie animale, I.N.R.A., 78350 Jouy-en-Josas, France
}

\begin{abstract}
Summary. The blastocysts were recovered from cows 7-10 days after oestrus and cultured. The zona pellucida has a spongy fibrous structure. Hatching begins, about $24 \mathrm{~h}$ after culture, through a relatively small hole out of which the blastocyst appears to escape by its own activity. Later the zona becomes split and the two edges of the slit surround part of the blastocyst. The emerging cells were large or small blastomeres which were generally covered by a dense mass of microvilli.
\end{abstract}

\section{Introduction}

As a criterion for testing cow blastocysts for their short-term developmental potentialities, we have used their ability to hatch in vitro. Whether the zona has been shed can be ascertained rapidly and it is a much more clear-cut assessment than, for example, increase in size. Furthermore, the number of blastocysts hatching is a measure of the adequacy of our culture conditions (Renard, du Mesnil du Buisson, Wintenberger-Torres \& Ménézo, 1976).

In the present study we examined mainly the ultrastructure of cultured blastocysts that were just beginning to hatch. The aim of the study was to describe the process of hatching of cow blastocysts as observed in vitro and to discuss the possible way(s) of zona shedding in vivo.

\section{Materials and Methods}

Blastocysts were obtained from cross-bred Charolais heifers. Superovulation was induced by the injection of 2100 i.u. PMSG between Days 9 and 11 of the cycle (Day $0=$ day of oestrus) followed $48 \mathrm{~h}$ later by an injection of $500 \mu \mathrm{g}$ Cloprostenol (ICI 80,996), a prostaglandin analogue. The animals were then inseminated twice with frozen semen at the time of oestrus, which was detected by testing with a vasectomized bull twice daily.

The heifers were slaughtered on Days $7-10$ of the induced cycle and embryos were recovered by perfusion of the uterine horns with phosphate-buffered saline $(290 \mathrm{mosmol}$; pH 7.2-7.4). Well developed blastocysts were selected with a stereomicroscope at $\times 40$ magnification. The diameters of the zona and of the vitellus of each blastocyst were measured with an ocular micrometer. More than 10 blastocysts at different stages of hatching and a few empty zonae pellucidae were prepared for scanning electron microscopy either directly after recovery or after culture for 24 to $72 \mathrm{~h}$ at $37^{\circ} \mathrm{C}$ in $0.5 \mathrm{ml} \mathrm{B} 2$ medium (Ménézo, 1976) under a gas mixture of $90 \% \mathrm{~N}_{2}, 5 \% \mathrm{O}_{2}, 5 \% \mathrm{CO}_{2}$, conditions which gave hatching of 31 out of a total of 47 blastocysts collected between Days 7 and 9 .

The blastocysts were fixed in $1 \%$ glutaraldehyde in cacodylate buffer $(\mathrm{pH} \mathrm{7.3)}$ and stored in the fixative. After washing in the cacodylate buffer, they were post-fixed in $1 \%$ osmium tetroxide and then subjected to critical-point drying in Freon or $\mathrm{CO}_{2}$, as described by Fléchon, Bergström, Jaszczak \& Hafez (1975). Some of the embryos were processed in carriers enclosed by grids of the standard type used for transmission electron microscopy (Taylor, 1975). Specimens were coated with carbon and gold-palladium and were observed at 15 or $20 \mathrm{kV}$. 


\section{Results}

\section{Zona pellucida structure}

The zona pellucida of the 7-10 day unhatched cow blastocyst appeared as a slightly rough continuous envelope ( $\mathrm{Pl}$. 1, Fig. 1). At higher magnification its structure appeared to be porous, at least in surface view (Pl. 1, Fig. 2).

The structure of the zona round embryos hatching in vitro did not appear to have changed significantly (Pl. 1, Figs 3 and 4). After hatching in vitro or in vivo the zona retained its original shape, and a slit, about half the perimeter long, was visible (Pl. 1, Fig. 5). In the angle formed by the edges of the slit through which the blastocyst had escaped, a fibrous configuration was observed within the zona (PI. 1, Fig. 6). Variable amounts of contaminant material were present on the zona before, during and after hatching (Pl. 1, Figs 1-6).

On Days 9 and 10, the mean \pm s.e.m. diameter of the zona of the unhatched blastocysts was 193.5 $\pm 28.4 \mu \mathrm{m}(n=21)$. On the same days, the diameter of the vitellus of the hatched blastocysts was $221 \cdot 8$ $\pm 42.5 \mu \mathrm{m}(n=17)$. Immediately after recovery, collapsed blastocysts were frequently observed inside a split zona. The mean \pm s.e.m. diameters of the vitellus and zona of these blastocysts were respectively $164.7 \pm 15.8 \mu \mathrm{m}$ and $188.4 \pm 16.7 \mu \mathrm{m}(n=19)$. Such blastocysts were not degenerating because they expanded in vitro.

\section{Blastocyst hatching}

The first blastomeres appeared through a hole in the zona pellucida and were of two kinds, small round cells and larger flattened epithelial-like cells (Pl. 2, Figs 7 and 8). Most of these cells (with only a few exceptions) were covered with a large number of microvilli (Pl. 2, Figs 7 and 8). The older blastocysts escaping through a larger split in the zona appeared slightly squeezed by the two edges of the slit (Pl. 2, Fig. 9). The trophoblast had a fairly uniform appearance and consisted of flat epithelioid cells. Nevertheless, it was possible to observe cells of different shapes and size, some large and flat, some slightly dome-shaped and some very small (Pl. 2, Figs 10 and 11). Sometimes, small round cells were present on the surface of blastocysts (Pl. 2, Fig. 9).

In blastocysts of 10 days or older (after culture in vitro), parts of the surface of some of the cells had few microvilli, for example, where the surface was slightly convex (Pl. 2, Figs 10 and 11). However, most blastomeres were uniformly covered with a dense mass of microvilli, amongst which a few cytoplasmic blebs were occasionally seen (Pl. 2, Fig. 12).

\section{Discussion}

The zona pellucida of the cow blastocyst appears to be viscous or adhesive because contaminants were seen on its surface, although they may have been precipitated during fixation or dehydration; it has a fibrillar spongy structure similar to that which has been observed by transmission and scanning electron microscopy of the eggs of other species (Zamboni, 1971; Fléchon et al., 1975; Dudkiewicz, Shivers \& Williams, 1976; Dudkiewicz, Williams \& Humphreys, 1976). Although the zona of mammalian eggs is known to consist of glycoproteins (Fléchon, 1970, 1974; Nicolson, Yanagimachi \& Yanagimachi, 1975) and to be digested by proteolytic enzymes and agents which split the disulphide bond (Inoué \& Wolf, 1974), the structure of the bovine zona was not profoundly changed during or after hatching: there was no uniform lysis, only perforation in one place.

The time of hatching of superovulated eggs in vitro, even after 3 or 4 days in culture, corresponds approximately with the time of zona loss in vivo (9-10 days after oestrus; Renard et al., 1976). As we were unable to collect blastocysts during the process of hatching in vivo, it is difficult to say whether the shedding of the zona in vivo was similar to that observed in vitro. However, the appearance of a zona pellucida from which a blastocyst had recently hatched at the time of flushing (Pl. 1, Fig. 5) supports this hypothesis; furthermore, empty zonae with equatorial slits were often found in the uterus in vivo 
at least until Day 13 after oestrus, a long period after the normal time of zona shedding. Although flushing the uterus may rupture the zona pellucida, our observations suggest that the process of hatching in the cow is the same in vivo as in vitro.

Comparison of the events described with those in the rabbit, a species in which dissolution of the egg envelope has been well studied (Denker \& Hafez, 1975), is difficult because the preimplantation rabbit blastocyst is surrounded by a mucin coat (Enders, 1971). In rats and mice the blastocyst may play an active role in hatching (Bitton-Casimiri, Brun \& Psychoyos, 1970; Bergström, 1972), or the uterus may be the principal site of activity (Mintz, 1970; McLaren, 1970). The zona pellucida seems to be torn by the hatching cow blastocyst, as indicated by the stretched fibres seen in the angle between the edges of the slit. Our observations on the diameter of blastocysts suggest that expansion and contractile activity may induce hatching; the diameter of the zona pellucida effectively increases because at the fertilized egg or early cleavage stages it is $\leqslant 160 \mu \mathrm{m}$. Unlike Wright, Anderson, Cupps \& Drost (1976), we did not measure the thickness of the zona; we would ascribe an eventual thinning of the zona before hatching to distension by the blastocyst rather than to lysis.

There has been no previous ultrastructural study of the early preimplantation embryo of the cow, as there has been for the ewe (Wintenberger-Torres \& Fléchon, 1974; Calarco \& McLaren, 1976). The small and round blastomeres of the 7- to 9-day-old cow blastocyst are similar to those described for baboon morulae (Fléchon, Panigel, Kraemer, Karter \& Hafez, 1976; Fléchon, Kraemer \& Hafez, 1977). Polar bodies may also be present even after hatching. In the 9- to 10-day-old blastocysts most of the surface blastomeres looked like the large ones of the younger embryos, although differences of size and shape still existed. In spite of a few exceptions the microvillous covering of the cow blastocyst appears very uniform, in contrast to that, for example, of the rabbit (Fléchon et al., 1975).

We are grateful to Bernadette Fléchon for preparing the blastocysts by critical point drying, to D. Chêne for printing the plates and to Marie-Elisabeth Matet for typing the text. We are indebted to Miss M. F. Hay for critically reading and improving the manuscript.

\section{References}

Bergström, S. (1972) Shedding of the zona pellucida of the mouse blastocyst in normal pregnancy.J. Reprod. Fert. 31, 275-278.

Bitton-Casimiri, V., Brun, J.L. \& Psychoyos, A. (1970) Contportement in vitro des blastocystes du $5 \mathrm{e}$ jour de la gestation chez la Ratte: étude microcinématographique. C. r. hebd. Séanc. Acad. Sci., Paris 270, 2979-2982.

Calarco, P.G. \& Mclaren, A. (1976) Ultrastructural observations of preimplantation stages of the sheep. J. Embryol. exp. Morph. 36, 609-622.

Denker, H.W. \& Haffz, E.S.E. (1975) Proteases and implantation in the rabbit: role of trophoblast vs. uterine secretion. Cytobiologie 11, 101-109.

Dudkiewicz, A.B., Shivers, C.A. \& Williams, W.L. (1976) Ultrastructure of the hamster zona pellucida treated with zona precipitating antibody. Biol. Reprod. 14, 175-185.

Dudkiewicz, A.B., Williams, W.L. \& Humphrfys, W.J. (1976) Interaction of rabbit sperm and egg. Examination of the same cryofractured specimens with scanning and transmission electron microscopy. Cell Tissue Res. 169, 277-288.

ENDERs, A.C. (1971) The fine structure of the blastocyst. In The Biology of the Blastocyst, pp. 71-93, Ed. R. J. Blandau. University of Chicago Press.

FLÉCHON, J.-E. (1970) Nature glycoprotéique des granules corticaux de l'oeuf de Lapine. Mise en évidence par l'utilisation comparée de techniques cytochimiques ultrastructurales. J. Microscopie 9, 221242.

FléchoN, J.-E. (1974) Application of cytochemical techniques to the study of maturation of gametes and fertilization in mammals. Multipurpose use of glycolmethacrylate embedding. Histochem. J. 6, 65-67.

Fléchon, J.-E., Bergström, S., Jaszczak, S. \& Hafez, E.S.E. (1975) Techniques for critical point drying of gametes and embryos. In SEM 1975, part I, pp. 325-331. Ed. O. Johari. I.I.T.R.I., Chicago.

Fléchon, J.-E., Panigel, M., Kraemer, D.C., Karter, S.S. \& HAFEZ, E.S.E. (1976) Surface ultrastructure of preimplantation baboon embryos. Anat. Embryol. 149, 289-295.

Fléchon, J.-F., Kraemer, D.C. \& Hafez, E.S.E. (1977) Observation par microscopie à balayage de stades précoces du développement embryonnaire chez le Babouin (Papio cynocephalus): ovocyte, pénétration de la zone pellucide et morula. $C . r$. hebd. Séanc. Acad. Sci, Paris 284, 223-225.

INOUÉ, M. \& WoLF, D.P. (1974) Comparative solubility properties of the zonae pellucidae of unfertilized and fertilized mouse ova. Biol. Reprod. 11, 558-565.

Mclaren, A. (1970) The fate of the zona pellucida in mice. J. Embryol. exp. Morph. 23, 1-19.

MÉnÉzo, Y. (1976) Milieu synthétique pour la survie et la maturation des gamètes et pour la culture de 
l'oeuf fécondé. C. r. hebd. Séanc. Acad. Sci., Paris 282, 1967-1970.

Mintz, B. (1970) Control of embryo implantation and survival. Adv. Biosci. 6, 317-342.

Nicolson, G.L., Yanagimachi, R. \& Yanagimachi, H. (1975) Ultrastructural localization of lectin-binding sites on the zonae pellucidae and plasma membrane of mammalian eggs. J. Cell Biol. 66, 263-274.

Renard, J.-P., du Mesnil du Buisson, F., WintenBerger-Torrfs, S. \& MéNÉzo, Y. (1976) In vitro culture of cow embryos from day 6 to day 7. In Egg Transfer in Cattle, pp. 159-164. Ed. L. E. A. Rowson. Commission of the European Communities, Luxembourg.

TAYLOR, P. G. (1975) A container for handling small specimens during preparation and examination in the scanning electron microscope. J. Microsc. 105, 335338.

WINTENBERGer-TORRES, S. \& FLÉCHON, J.-F. (1974) Ultrastructural evolution of the trophoblast cells of the pre-implantation sheep blastocyst from day 8 to day 18. J. Anat. 118, 143-153.

Wright, R.W., Jr, Anderson, G.B., Cupps, P.T. \& Drost, M. (1976) Blastocyst expansion and hatching of bovine ova cultured in vitro. J. Anim. Sci. 43, $170-174$.

Zamboni, L. (1971) Fine Morphology of Mammalian Fertilization. Harper \& Row, New York.

\section{EXPLANATION OF PLATES}

\section{PLATE 1}

Fig. 1. General aspect of the zona of an unhatched 10-day cow blastocyst.

Fig. 2. Higher magnification showing the spongy structure of the surface of the zona.

Fig. 3. General aspect of the zona of a hatching blastocyst, cultured in vitro from Day 9 to Day 10 .

Fig. 4. Higher magnification of the same zona. Comparable view to that shown in Fig. 2.

Fig. 5. Empty zona after early hatching in vivo (Day 7); an extruded blastocyst was found at the same time. Note the retention of the spherical shape and the open slit.

Fig. 6. The angle between the two edges of the zona slit stretched by a hatching blastocyst cultured from Day $9 \frac{1}{2}$ to Day $10 \frac{1}{2}$. The inner part of the zona has a fibrillar structure. The surface of a blastomere is visible in the lower half of the picture.

\section{PLATE 2}

Fig. 7. Early phase of hatching through a small hole of the zona round a blastocyst cultured from Day 7 to Day 9.

Fig. 8. Detail of the extruded cell mass of the same blastocyst: large and small blastomeres are segregated and all are covered by microvilli, except for the blastomere(s) on the top of the cell mass which have no microvilli, only a few blebs.

Fig. 9. Blastocyst almost completely extruded from a half-opened zona after culture from Day $9 \frac{1}{2}$ to Day $10 \frac{1}{2}$. Small round cells are visible on the surface of the blastocyst which looks larger in diameter than the zona.

Fig. 10. Higher magnification of the surface of the blastocyst close to the zona (top): the blastomeres are generally large and uniformly covered by microvilli, with exceptions (arrows).

Fig. 11. Varied appearance of trophoblast: large blastomeres, sometimes showing areas with few microvilli (white arrow), and small blastomeres (black arrow heads), near the zona (top) of a hatching blastocyst. Same treatment and age as in Fig. 9.

Fig. 12. Usual appearance of the microvilli on a hatching blastocyst cultured from Day 9 to Day 10 . A few cytoplasmic blebs are visible; the zona edge is at lower left corner. 

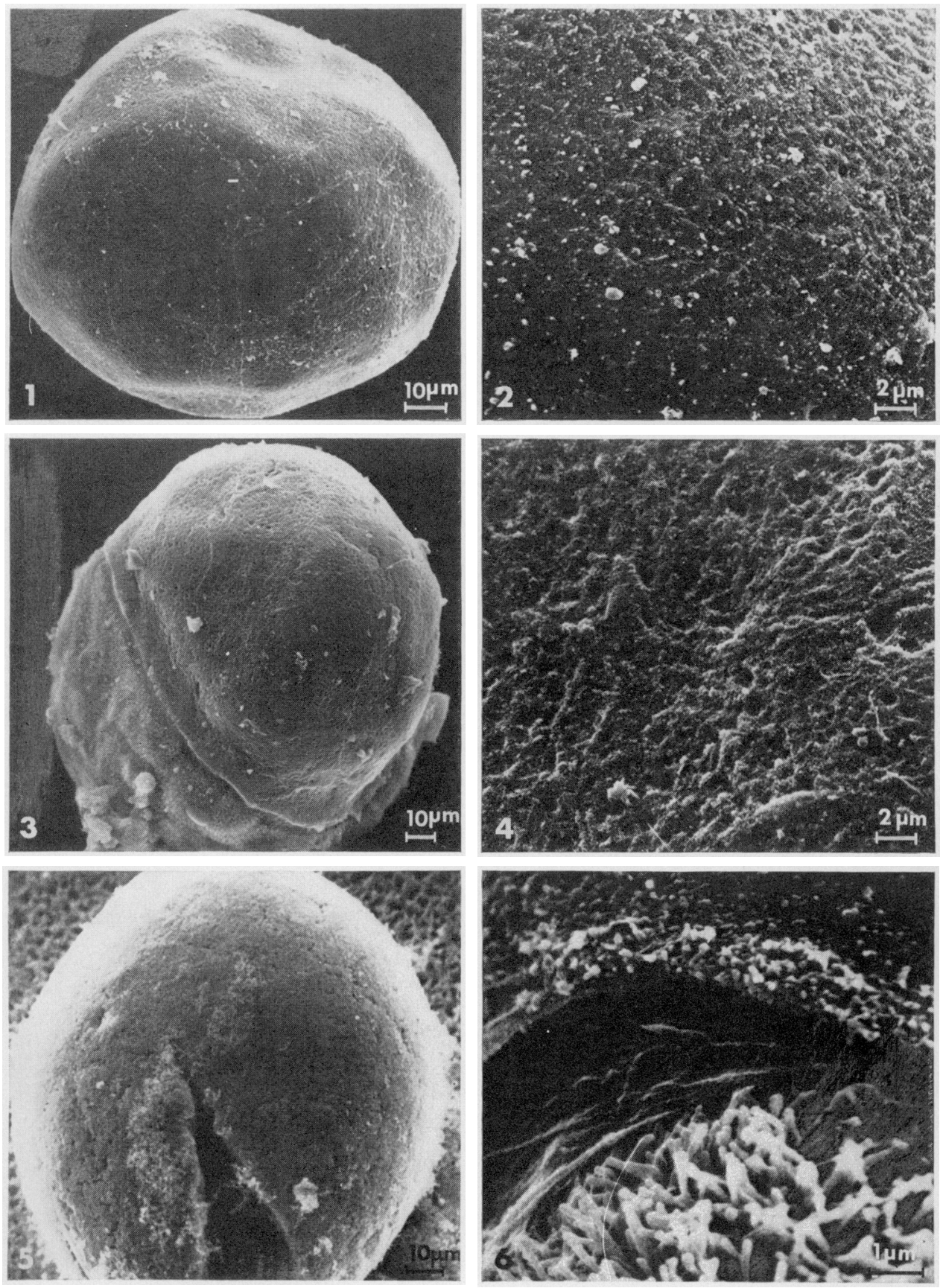

(Fucing p. 12) 

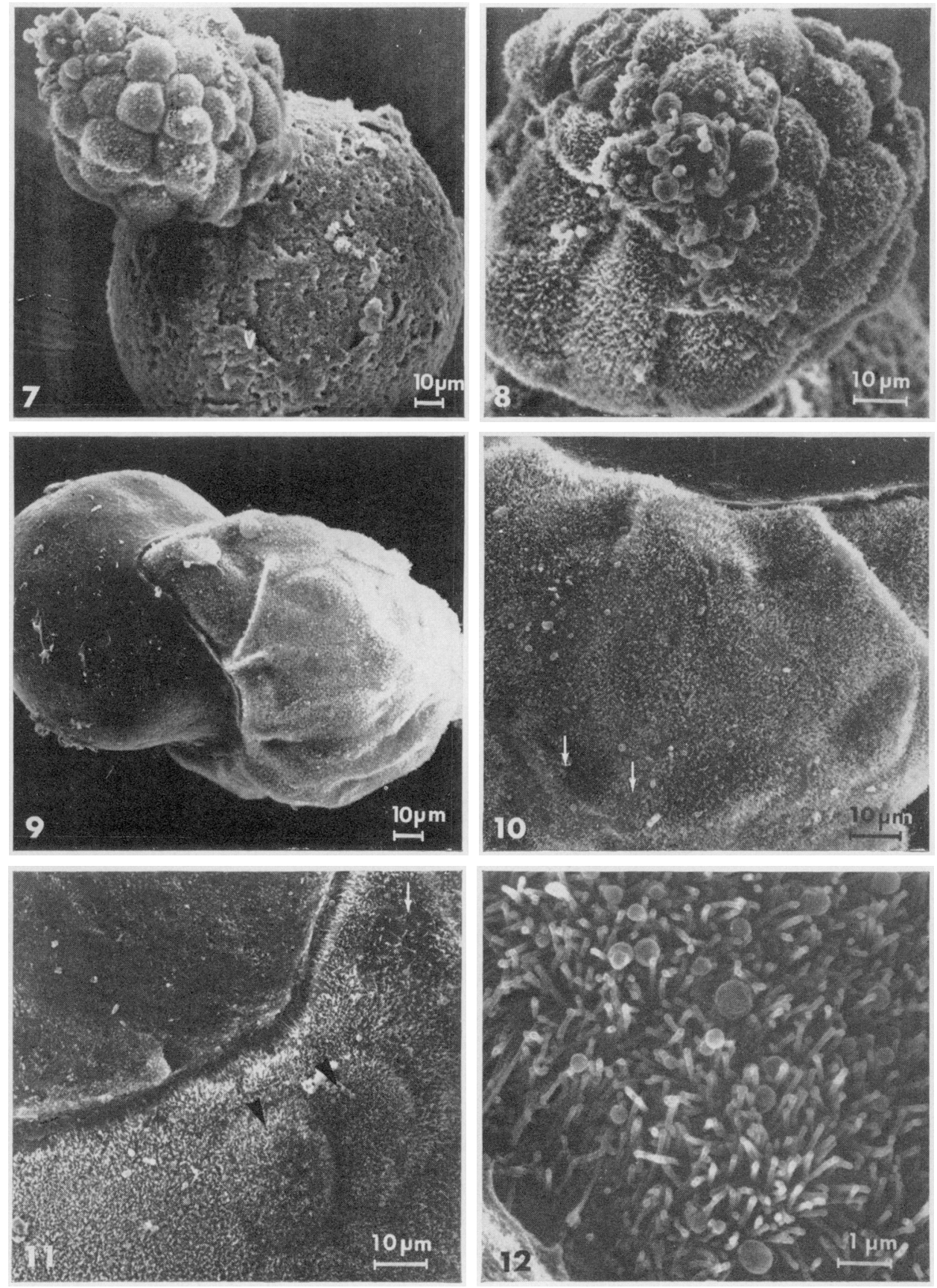